\title{
Development of Risk Assessment Framework for Political Risk Guarantee in Public-Private Partnership Projects
}

\author{
Andre Permana, Robert Tiong Lee Kong \\ Nanyang Technological University, Singapore
}

Corresponding author:

andrepm01@gmail.com

\section{ABSTRACT}

In Public-Private Partnership (PPP) projects, guarantees can be regarded as a government fiscal support. Due to its uncertainty, one of the key challenges in guarantee valuation is to define appropriate assumptions for underlying risk factors since infrastructure projects are not assets that can be explicitly linked to an observable market price. While very few governments formally measure them, it is also found that sometimes the assessment on political risk covered by the guarantees is highly subjective and ambiguous. This paper proposes a methodology that combined quantitative and qualitative approach for contingent liabilities assessment for PPP infrastructure projects with focus on political risk. It uses fuzzy sets based risk assessment that quantifies expert opinion on likelihood and impact of risk factors into an input to quantitative risk analysis. A particular developing country is chosen so that the proposed methodology can be applied according to the country and infrastructure sectors specific context.

Keywords: risk assessment, contingent liabilities, political risk, guarantee valuation, infrastructure projects

\section{SARI PATI}

Dalam proyek-proyek Kerja Sama Pemerintah dan Badan Usaha (KPBU)), jaminan dapat dianggap sebagai dukungan fiskal pemerintah. Karena ketidakpastiannya, salah satu tantangan utama dalam penilaian jaminan adalah menentukan asumsi yang tepat untuk faktor risiko yang mendasari, karena proyek infrastruktur bukan aset yang dapat dikaitkan secara eksplisit dengan harga pasar yang dapat diamati. Meskipun pemerintah jarang mengukurnya secara formal, ditemukan juga bahwa kadang-kadang penilaian atas risiko politik yang tercakup dalam jaminan sangat subjektif dan ambigu. Makalah ini mengusulkan sebuah metodologi yang menggabungkan pendekatan kuantitatif dan kualitatif untuk penilaian kewajiban kontingensi, untuk proyek infrastruktur KPBU dengan fokus pada risiko politik. Metode ini menggunakan himpunan fuzzy berbasis assesmen risiko yang berdasarkan penilaian yang mengukur pendapat ahli tentang kemungkinan dan dampak faktor risiko menjadi masukan terhadap analisis risiko kuantitatif. Satu negara berkembang dipilih, sehingga metodologi yang diusulkan dapat diterapkan sesuai dengan konteks sektor negara dan infrastruktur.

Kata Kunci: risk assessment, contingent liabilities, political risk, guarantee valuation, infrastructure projects 


\section{INTRODUCTION}

Direct and indirect supports from host governmentarenotuncommon to beimplemented in privately financed infrastructure projects such as Public-Private Partnerships (PPPs). Provision of government support is essential for PPPs in striking trade-offs between risk and return in favor of seeking optimal risk allocation (Ye 2001). However, Tiong (1995) suggests that a successful BOT promoter should not press the governments for unreasonable financial support (e.g. guarantee) that will upset governmental policies and accountability to the public. To gain optimal impact on its attractiveness to investors and on the government fiscal capacity, the guaranteed project has to be financially and economically feasible.

On guarantees, governments can easily make poor decisions as they tend to have a preference for such contingent support over direct support. These supports do not come cheaply as they are representing potentially sizable contingent liabilities to the government, which are triggered by a particular discrete event, which may or may not occurs (Brixi 1999). Consequently, it is crucial for the government to quantify or to measure the cost of its risk exposure from these liabilities. For privately financed infrastructure projects, the key purposes of the assessment by government are to ensure that sufficient level of reserves in its budget is maintained for contingent liabilities in case of fiscal crises and to evaluate options of fiscal supports for projects (Lewis 1998; Mody 2002).

Estimation of expected losses is the most common measures used for contingent liabilities assessment. Some quantitative techniques, as described by Almeyda and Hinojosa (2001), are available to quantify different types of contingent liabilities which depend on the type of risk being analyzed. The valuation exercise using Value at Risk (VaR) or option pricing based analysis is typically combined with stochastic simulation approach such as standard Monte Carlo sampling in risk analysis application (Lewis 1998; Irwin 2003). Others used the Latin Hypercube sampling technique, as in Saliby and Pacheco (2002), that is employed to value the guarantee in Indonesian toll road project (Wibowo 2004). However, a key challenge in applying this approach is to define appropriate assumptions for underlying risk factors since infrastructure projects are not assets that can be explicitly linked to an observable market price. Defining the risk factor's stochastic parameters quantitatively may result in very complex and impractical situation.

Irwin (2007) has suggested that a qualitative analysis can be regarded as best supplement for the analysis of the appropriate risk allocation which can affect on the total value of a government guarantee. For example to assess the value of political risk guarantees, in the absence of objective and historical data, it is found that sometimes it is highly subjective and ambiguous. Moreover, political risk is unique since the main cause of the risk and the contracting authority is one single party that is government. Consequently, losses that resulted political (in)actions would be mainly bear by the government itself. This special fact would even further characterize the vagueness and subjective nature of political risk guarantee, particularly in the assessment of its likelihood and impact. Thereby, qualitative risk assessment is essential to be included in the contingent liabilities valuation from political risk and chosen for the work presented in this paper.

This paper proposes an integrated risk assessment methodology that combined quantitative and qualitative approach for PPP infrastructure projects especially on contingent liabilities from political risk. The methodology aimed to estimate stochastic parameter of political risk factors for contingent liabilities assessment comprehensively. It employs fuzzy sets based 
risk assessment in quantifying expert opinion on risk factors into an input to quantitative risk analysis by converting the aggregated opinions represented by membership functions into risk profile specific and customized probability distribution functions (PDF) for stochastic simulation analysis.

\section{LITERATURE REVIEW}

Fuzzy-Based Techniques for Political Risk Assessment

Political risk assessment (PRA) is conducted for many purposes such as functioning as a basis for underwriting activities of PRI providers (Wagner 1999), or for judgment of new credit in banks (Kosugi 2006). PRA can be combined with quantitative approach for risk analysis such as integration to capital budgeting process, in the context of investment appraisal. It can be achieved by adjusting the discount rate of cash flow (Shapiro 1978) or by the valuation of political risk as insurance policy (Clark 1997) or as financial option (Mahajan 1990), as most of them are focusing only to the modelling of expropriation risk than other types of political risk.

In contingent liabilities valuation for political risk guarantees, the qualitative approach of PRA is adopted as the part to collect required information on risk event likelihood in question. Instead of guessing on the most likely outcomes, the easiest and the common approach is subjective probability method which contributes in probability distribution elicitation from the expert or relevant respondents. To eliminate the biases and to increase the accuracy of the final probabilities, hierarchical method is applied in conjunction with engagement of multiple experts. Two main techniques of combining the probabilities from multiple experts are aggregating individual assessments and group consensus. In most cases, aggregating by simple averaging performs well, but more complex modelling rules can be used if information about the quality of and dependence among the experts' assessments is available (Clemen 1999).

While probability theory has been used almost exclusively to deal with the form of uncertainty due to chance (randomness, sometimes called variability), fuzzy logic is argued to be appropriate when handling other prevalent forms of uncertainty which are arising from ambiguity, vagueness, and imprecision (Zadeh 2002). For country risk assessment, fuzzy logic was adopted to a framework to support global market entry decision (Levy 1995).

Recently, Sachs (2008) uses a fuzzy sets based methodology for risk exposure assessment under guarantee used in a privatized water project. It allows conversion of qualitative information into an input of quantitative risk analysis. In the lack of actuarial data, it tries to quantify expert opinion on likelihood and impact of risk factors which is then used as a discount factor to the base case cash flow. However, this method is greatly depends on the skilful drafting of the qualitative questions and good choice of "knowledgeable" respondents since case by case nature of the assessment context is sometimes very specific (e.g. the risk assessment in perspective of different parties in a particular project)(Sachs 2009). Therefore, it is difficult to ensure that the amount of converted qualitative information is equivalent to the opinion specified by the respondent. Another drawback is that, the survey scale obtained from the respondent seems not sufficient for conversion of the aggregated trapezoidal membership function to probability distribution function (PDF) as it is not an interval or a ratio scale as the probabilistic scale of the PDF parameters. Else, it also not clear as the converted PDF is not specifically refers to a particular type of PDF.

In this research work, these issues are addressed to enhance the methodology as it is 
implemented in conjunction with contingent liabilities analysis for guarantee valuation from perspective of government in PPP infrastructure projects. The conversion from fuzzy set measures towards probabilistic measures (e.g. parameters of specified type of PDF that resembles the political risk event in question) is refined through the elicitation of survey in 2 stages that is based on the assessment context and the probabilistic nature of the scale. To apply this to value the government guarantee by quantitative risk modelling \& simulation in several actual PPP projects from different sectors as case study in a specific developing country (i.e. Indonesia). The main reason is that the project specific risk profile that generates certain set of political risk events is required to obtain relevant result based on the risk assessment context.

\section{Fuzzy Set Theory for Estimating Probability of the Risk Event}

A fuzzy set $\mathrm{F}$ in a universe $\mathrm{U}$ is a collection of ordered pairs $s$, where $\mu_{\mathrm{F}}: \mathrm{U} \rightarrow[0,1]$ is the membership function of $F$. Specifically, ${ }_{\mathrm{F}}(u)$ is the membership grade of $u$ in $F$, which measures the compatibility of $u$ with $F$. $\mu_{\mathrm{p}}(u)$ may also be regarded as the degree of truth, or possibility, that $u$ belongs to $F$. (s). The closer the object matches the vague predicate, the higher its grade of membership. The membership function (MF) may be viewed as representing an opinion poll of human thought or as an expert's opinion. Here, it is clear that the main idea of adopting fuzzy set theory as the approach to achieve the research objective is to estimate probability of an event occurring from degree of membership of particular relevant factors to the event. Thus, the higher the grade of these factors in the membership function of an event, the higher the probability of the event will be occurring as more of the elements of the risk factor characterize the risk event. Below is the description of development of the fuzzy logic based methodology, followed by how it is applied in the political risk assessment for government guarantee valuation.

\section{Selection of Trapezoidal Fuzzy Numbers}

One type of MF is trapezoidal fuzzy numbers (TrFN). They are characterized by the quadruples "a", "b", "c", and "d" that are ascending on a scale, and the membership of "a" and "d" is zero and that of "b" and "c" is one. It is $a \leq b \leq c \leq d$ and $\mu(a, d)=0 ; \mu(b, c)=1$ for $\{a, b, c, d\} \in R^{+}$.

Figure 1 shows a graphical representation of a fuzzy number.

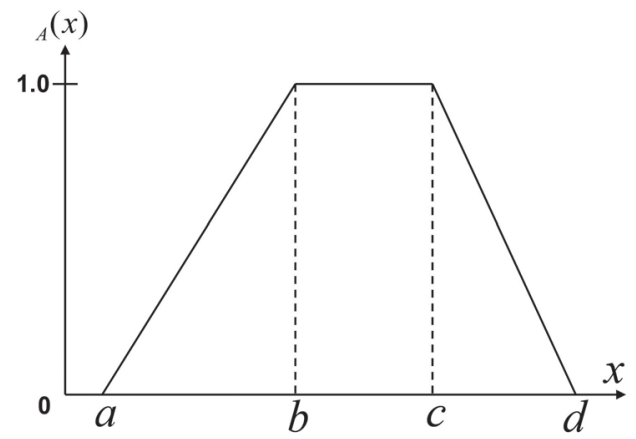

Figure 1. Membership Function of Trapezoidal Fuzzy Numbers

In the case where $b=c$, this $\operatorname{TrFN}$ becomes $a$ triangular fuzzy number (TFN). Implementing the TFN is mathematically straightforward. TFN parameters are analogous to the lower, medium, and higher values in the domain of the triangular probability distribution. However, the parameters in a TFN represent the values accorded by human thought to the possibility of an event occurring, while the parameters in a triangular probability distribution represent the values associated with the probabilistic occurrence of that event.

For purpose of this paper, to ease the calculation of inferential logic, trapezoidal fuzzy numbers (TrFN) was selected for conversion to PDF. One of the considerations is because TrFN provides more information on the risk as it has more representing points than TFN on its membership function. Furthermore, for the survey scale 
assignment, the TrFN gives more convenient way to respondent as it is symmetrical fuzzy numbers and more easier to be adjusted to probabilistic scale.

\section{Fuzzy Operation on Membership Functions}

Basically, manipulations of membership functions require three basic fuzzy set operations, complementation, intersection, and union, which are typically defined as follows. Let $A$ and $B$ be fuzzy sets in $U$, i.e. $A, B \in U$. The complement $A$ of $A$ is the fuzzy set with membership function:

$\mu_{\hat{A}}(u)=1-\mu_{A}(u)$.

The intersection of A and B is the fuzzy set $\mathrm{C}=\mathrm{A} \cap \mathrm{B}$ with:

$\mu_{C}(u)=\mu_{A}(u) \wedge \mu_{B}(u)$,

where $a \wedge b$ means $\min \{a, b\}$. The union of $A$ and $B$ is the fuzzy set $D=A \cup B$ with:

$\mu_{\mathrm{D}}(\mathrm{u})=\mu_{\mathrm{A}}(\mathrm{u}) \vee_{\mathrm{B}}(\mathrm{u})$,

where $a \vee b$ means $\max (a, b)$.

\section{Aggregation of fuzzy numbers of risk factors}

For the political risk assessment, the expert opinions of the risk factors are specified by fuzzy numbers in different observation period (e.g. project phases). On each type of political risk as the guarantee coverage, the political risk events $i$, with $i=[1,2, \ldots, n]$ are identified and structured in the upper level of the influence diagrams (see Figure 2). Then, the risk factors for each risk event $i, r=[1,2, \ldots, n]$ are arranged in the lower level. Thus, information on the specified risk factor's degree of relevance $(R)$ and degree of impact $(I)$ is denoted with fuzzy numbers.

The influence diagram is essentially useful to show the consensus on expert opinions is achieved through the aggregation of these risk factors. There are 2 types of combination, namely vertical aggregation (between risk factor's level) and horizontal aggregation (between respondents).

\section{Aggregation between respondent's fuzzy numbers}

This aggregation is about constructing a knowledgebase of expert opinions on trapezoidal fuzzy numbers (TrFN) which for that a separated survey must be conducted. The survey is basically carried out to obtain the interval type of scale. It is directed on the 0 to 7 fuzzy linguistic scales which are plotted individually by respondents to the numerical interval of 0 to 1. The different numerical representations on the same linguistic term were aggregated for each quadruple by:

$$
A(X)=\sum_{t=1}^{k} c_{i} A_{i}(X), \text { with } \sum_{t=1}^{k} c_{i,}=1
$$

where $A_{i}(X)$ denotes the valuation of the proposition " $\mathrm{x}$ belongs to $\mathrm{A}$ " by respondent $\mathrm{i}$, " $C_{i}$ "

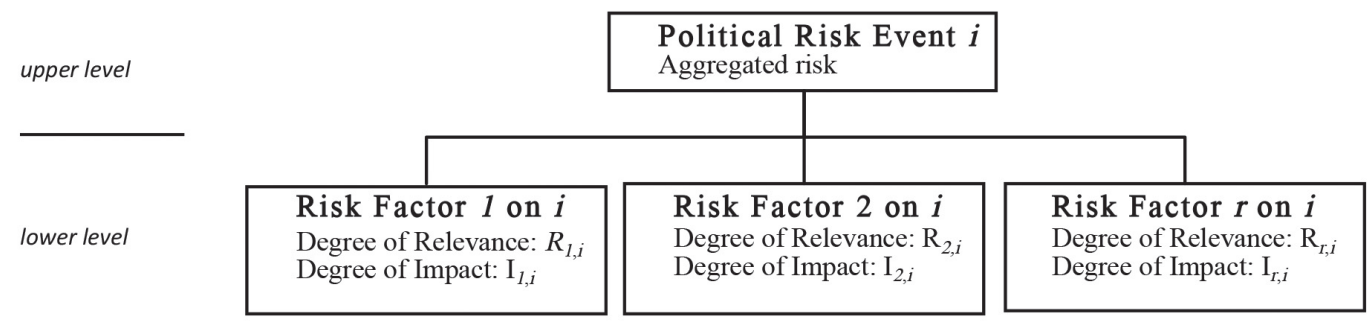

Figure 2. Influence diagram of risk factors 
Table 1. Numerical representation of expert opinion

\begin{tabular}{cccccc}
\hline Numerical & Linguistic & \multicolumn{4}{c}{ Tr.F.N. Representation } \\
\cline { 3 - 5 } Values & values & $\mathrm{a}$ & $\mathrm{b}$ & $\mathrm{c}$ & $\mathrm{d}$ \\
\hline 0 & Not applicable & 0.000 & 0.000 & 0.000 & 0.000 \\
1 & Extremely low (EL) & 0.000 & 0.000 & 0.113 & 0.195 \\
2 & very low (VL) & 0.130 & 0.210 & 0.270 & 0.350 \\
3 & low (L) & 0.235 & 0.310 & 0.373 & 0.440 \\
4 & medium (M) & 0.340 & 0.425 & 0.520 & 0.610 \\
5 & high (H) & 0.515 & 0.593 & 0.675 & 0.765 \\
6 & very high (VH) & 0.660 & 0.735 & 0.815 & 0.890 \\
7 & Extremely high (EH) & 0.795 & 0.865 & 1.000 & 1.000 \\
\hline
\end{tabular}

is the weight attributed to each expert, and " $k$ " is the number of expert opinions collected. Table 1 shows an example of the resultant of fuzzy coded linguistic terms in numerical representation.

\section{Aggregation between different risk factor level}

Furthermore, the opinions collected from the experts on the relevance (R) and impact (I) on risk factors $t=(1,2, \ldots, \mathrm{k})$ by respondent $i$ are aggregated by the Fuzzy Weighted Mean (FWM) method for each tier in the influence diagram. In calculating the FWM, as in (Sachs 2009), the simplified arithmetic operations (SAO) are chosen for addition, multiplication, and subtraction while Minkowski division is used for division of fuzzy numbers. Then, the FWM is written as follows.

$$
I_{i}=\frac{\sum_{t=1}^{k} R_{i, t} I_{i, t}}{\sum_{t=1}^{k} R_{i, t}}
$$

To represent effect of the mitigating measures, as will be explained later in section Error! Reference source not found., SAO is used for subtraction of fuzzy numbers.

Converting a fuzzy number into its corresponding probabilistic density function (PDF)

The conversion of the membership function of a fuzzy number, $\mu_{A}(x)$, into a probability density function, $f(x)$, can be achieved by using one of the two linear transformations presented in Yoon (1996) that follows Kaufmann and Gupta (1985), i.e.

proportional probability density function:

$\mathrm{p}(\mathrm{x})=\mathrm{h}_{\mathrm{p}} \mu_{\mathrm{A}}(\mathrm{x})$

uniform probability density function:

$\mathrm{u}(\mathrm{x})=\mu_{\mathrm{A}}(\mathrm{xP})+\left(\mathrm{h}_{\mathrm{u}}-1\right)$

where $h_{p}$ and $h_{u}$ are the conversion constants which ensure that the area under the continuous probability function is equal to one. Figure 3 shows how fuzzy numbers are used for the conversion of trapezoidal MF to a PDF. The conversion of a fuzzy number into its corresponding proportional distribution is computationally straightforward. However, according to Sheen (2002), when the uniform method is used both the domain and the range of the resulting distribution are reduced (or increased). The reduced (or increased) domain indicates the partial rejection (or addition) of some members from (or to) the set. Hence, this particular conversion method is not entirely suitable.

Furthermore, when applying the proportional method to convert the fuzzy number, it is noted that the range of the membership grade of the resultant distribution is greatly reduced when the fuzzy number has a wide domain. Consequently, the ability of the membership function to discriminate precisely among members of the 

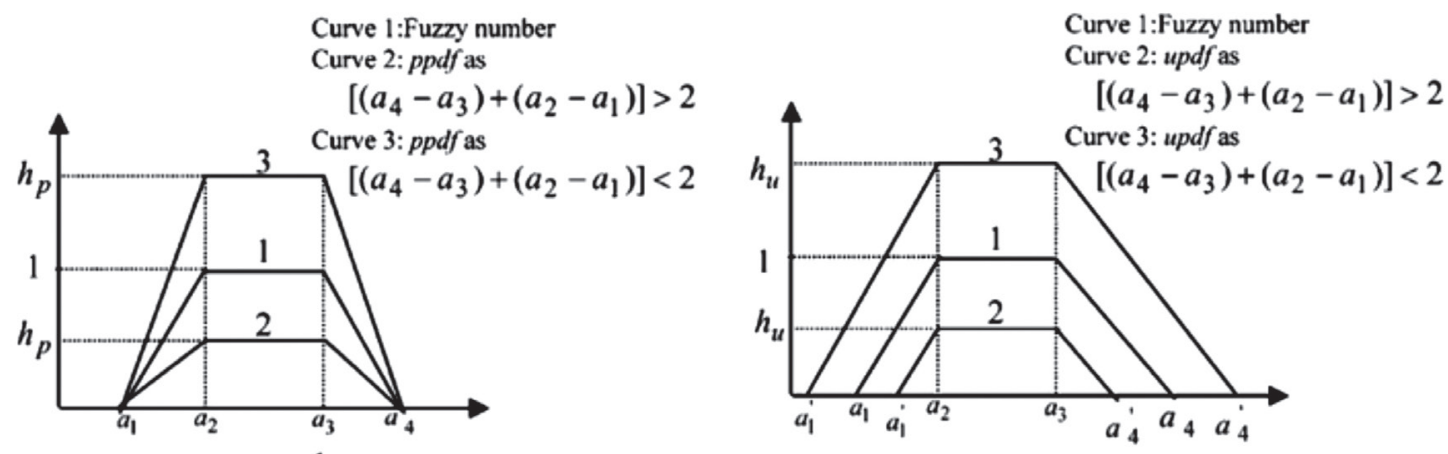

Figure 3. Conversion of Trapezoidal Membership function into PDF

fuzzy set is impaired. Fortunately however, the domain of fuzzy numbers used to denote an expert's knowledge is always sufficiently narrow to avoid this becoming a problem. Therefore, in view of the limitations of the uniform method, it is recommended that the proportional method be applied when comparing fuzzy numbers and therefore is selected for this research work.

Adjustment of Fuzzy Scale to Probabilistic Scale The numerical interval obtained, as in Table 1, is adjusted to probabilistic scale by multiplying each fuzzy linguistic scale with a conversion factor. This conversion factor is obtained from the maximum probabilistic scale (e.g. frequency of a risk event) comparable to highest linguistic value that we asked earlier to the respondents. The final adjusted scale gives the resultant fuzzy coded linguistic terms in the probabilistic measures which will be used for the conversion of aggregated membership function to the corresponding PDF parameters.

\section{Numerical Example of the PDF Conversion from Membership Function}

A numerical example is presented to illustrate how the conversion works for the trapezoidal fuzzy linguistic scale assigned from the respondents into the PDF parameters. Say, for expropriation risk event which is perceived extremely high by the respondent can be translated as having relative frequency of 25\% which the value substitutes the probability of that risk event given the risk factor's relevance and impact. Then, in the case of expropriation risk, the mean value of the converted PDF from the fuzzy membership function is 0.352. Then, the probability of expropriation event in the light of fuzzy information from expert opinion can be calculated as,

$$
P\left(E x \mu_{E X}(x)\right)=(0.352) .25 \%=0.088 \%
$$

This value of probability will be used as the value of the parameter in the probability distribution function type that fits into characteristic of the observed risk event in the particular project context which is used for quantitative risk modelling and simulation for the guarantee valuation exercise.

\section{Assessment of Stochastic Attributes of Risk} Factors on each Political Risk

This step is really the heart of the proposed methodology. This part is mainly using the qualitative approach of fuzzy set-based risk assessment. Expert opinions are collected through survey by questionnaire and interview.

\section{Selection of Political Risk Factors.}

The political risk factors are obtained and summarized from list of relevant factors that are usually used for underwriting political risk insurance (see 6.1 in Appendix). Public and private insurer's perspective on the political risk guarantee risk factors are adopted to provide fair 
and objective platform of the assessment. Here, therefore a risk factor is defined as relevant factor associated with risk in the observed project and country.

The rationale is that these factors are formulated from the guarantor viewpoint and are distinct from list of factors for country rankings with regards to political risk. The guarantor focuses on the estimation of capital required to balance the value of risk exposure from the guarantee claims triggered by the occurrence of particular political risk event. In favor of government as the guarantor, the amount of capital used to compensate project company's losses (i.e. guarantee claim payment) can be regarded as the value of contingent liabilities. With the standpoint that the nature of PRI is analogous to government guarantee for political risk, with particular distinctions, these risk factors are adopted and applied to assess the likelihood of the type of political risk in question.

Emphasizing the distinction to country risk assessment, this PRA is only concentrating on the one project that being evaluated (project specific). However, the nature of risk factors is not only project-specific but also can be sectorspecific and country specific. These factors are also distinct in 2 other different forms, namely given condition (e.g. based on the given circumstances) and risk mitigating measure. The distinction is made for representing the effect of mitigating measures in risk assessment which may somehow negating the risk exposures from non-mitigating measure aggregated risk factors.

\section{Degree of Relevance and Degree of Impact for Assessing of Political Risk Events}

The risk factor's assessment is basically conducted by applying numerical or linguistic values selection using survey scale as shown in Table 1. As commonly used, for instance in , risk is universally defined by 2 parameters which are the frequency or the likelihood of the risk event and the severity of the risk event. As the proxies in the qualitative assessment, this methodology uses degree of relevance for the former and degree of impact for the latter. Degree of relevance is distinguished from the degree of impact by emphasizing that the previous only deals with the intensity of relationship between 2 factors in question, while the later measures the influence of one factor to another. In the survey, the list of risk factor is summarized for each type of political risk in question. The every risk factor is assessed based on the 2 parameters in relation to the particular type of political risk. For example, as one of the risk factors of expropriation risk, the project impact to the domestic economy is assessed for the relevance using question drafted as,

"How is the degree of relevance of this risk factor to expropriation risk (in the observed project and for the observed period that is defined earlier)?"

Similarly for the impact assessment, the factor is assessed using question drafted as,

"How is the degree of impact of this risk factor to expropriation risk (in the observed project and for the observed period that is defined earlier)?"

In addition to the 2 parameters assessment, the result recognizes the effect of risk factors that are categorized as the mitigating measures for particular political risk. For such risk factors, such as 'international experience of the project investor' for expropriation risk, this effect is represented by obtaining the smaller degree of membership when the assigned scale by the respondent is higher.

\section{Selection Criteria of Experts as Respondents}

Unlike typical statistically evaluated survey with questionnaires, this methodology relies greatly on the quality of the selected respondents in terms of their relevance and specific knowledge to the projects being assessed. Therefore, each project requires only few numbers of respondents. To select project-specific 
respondents, rather stringent but practical criteria are used. They are:

a. Well informed: In-depth understanding and specific knowledge and experience especially with political risks involved in the project being assessed is desired. Or, he/she must be regarded to have sufficient knowledge and experience related to PPP infrastructure project in the specified country (Indonesia) and similar sector with the project in question.

b. Provide objective judgment: The selected respondents must not have any direct involvement and influence to the beneficiary of guarantee in the PPP project.

c. Diversified: He/She can reflect different point of views (as they can be from private sectors or public sector or academics) and have different background such as industry practitioners (e.g. lender, investor, consultant) and/or as decision makers (e.g. manager, director, analyst)

d. Accessible and willing to participate

\section{Comparison with Subjective Probability} Assessment

As explained above, the nature of results of the risk assessment for the guarantee valuation (also in insurance underwriting) for political risk is subjective as it mainly based on expert judgment information. There is little (if any) quantitative data that can be used for actuarial approach to estimate the guarantee claims probability and magnitude. Therefore, to demonstrate the robustness of the proposed fuzzy based method, subjective probability approach is used on the purpose of comparison on the results. Another way that might be possible for comparison is to contrast the results with political risk insurance premium rates for comparable risk coverage. To keep the simplicity of the paper, only the prior method is presented and discussed.

The subjective probability approach method used in this research work simply asks respondents on likelihood of trigger events (particular set of circumstances that caused occurrence of risk) of the specific political risk using survey scale of 0 to 100 , in percentage scale. As the output, the aggregated subjective probability of each trigger event in the form of PDF of each specific political risk. Here, the method of simple averaging with is chosen seems sufficient to aggregated subjective probability as suggested in (Clemen 2006).

$\rho^{*}=\sum_{i=1}^{n} \beta_{i} \cdot \rho_{i}$

while $\beta_{1}=$ weighting factor of respondent $i$, so that $\sum_{i=1}^{n} \beta_{i}=1$ to ensure aggregated $p^{*}$ is probability, and $p_{\mathrm{i}}=$ probability assigned by respondent $i$, The resulting $p^{*}$ is a convex combination of $p_{i}$, with the coefficient interpreted as being directly proportional to the amount of information each expert has.

\section{EVALUATION OF CONTINGENT LIABILITIES EXPOSURES}

Contingent liabilities exposure evaluation is conducted for each individual project requesting for political risk as the guarantee coverage. It involves several stages, including stages on project document and data preparation, defining and modeling the government risk exposures, and the stochastic simulation analysis that enables the discussion on findings and recommendations.

\section{Preparation for Project Definition and the Assessment Context}

The commitment of government regarding political risk can be found in contractual project documents (e.g. project contract clauses, letter of guarantee) and the risk allocation section of the project feasibility study document used for tender solicitation for investor/sponsor. For that reason, the project data availability (project contractual agreement, financial model) is 
essential for a sensible outcome on contingent liability measures.

Basically, this risk evaluation take place before the PPP contract award (e.g. during the project's bidding process). The exercise is conducted by team of analyst to support the decision making process on government guarantee policy by Minister of Finance (MoF) or in other technical ministries (e.g. Ministry of Public Work) who proposes the amount and coverage of government guarantee to be approved by the MoF. In both cases, the team can be responsible for estimating the adequate amount for budgeting of capital reserve to serve the guarantee claim payment.

\section{Preparation of Base Financial Model}

To the contracting agency as part of government that would assess and authorize the guarantee, it is important to evaluate the draft contract agreement and the project financial model as the basis for guarantee valuation. Both data are vital in obtaining relevant assumptions as the primary requirements of contingent liabilities modelling in a spreadsheet format. Especially for the financial model, it is usually obtained as part of the Project Feasibility Study conducted in conceptual stage or early stage of design development. These sets of relevant assumptions would then be outlined as the most likely scenario or a base case model for further simulation analysis.

\section{Assumption and Risky Variables}

In this government perspective model, variables that represent controllable risks by government such as construction cost and $0 \& \mathrm{M}$ cost are assumed as deterministic variables while the opposites such as inflation rate and traffic volume (e.g. for toll road) are assumed as stochastic variables. Then, some key assumptions that can be derived from relevant historical data are the risk free rate, the beta $(\beta)$ of relevant type of project being observed and the cost of debt. As these values could be useful for ex-ante valuation approach, they also used to estimate the required cost of equity and the cost of capital used for the project capital budgeting and the ex-post valuation approach.

\section{Defining Government Risk Exposures}

It involves the identification government risk exposures from its commitment to the project company and the modelling appropriate stochastic parameter for the risk event. Both tasks are really dependent on the extent of the explicit contingent liabilities from contractual project agreement between the government and the project company. Therefore, the evaluation outcome depends on how close the modelling of the risk exposures to the actual compensation payment by government due the contingent guarantee trigger event. For instance, government risk exposures from expropriation risk is merely based on the formula of compensation payment by government to private partner as a consequence for premature contract ending either due to optional termination or default by government in PPP projects (including expropriation and default by public authority).

\section{Valuation of Guarantee}

The type of guarantee valuation method use here is Value at Risk (VaR) considering the guarantee event is expressed as discrete event. The method will be combined with Monte Carlo simulation. And finally the final output of the risk assessment is the magnitude of guarantee cost that is shown in range of guarantee values with associated confidence intervals as result of stochastic simulation on the financial model. From this outcome, it is possible to formulate recommendation of periodic reserve budgeting based on the guarantee impact on project feasibility.

The Framework Implementation on the context of Indonesia PPP Projects

To demonstrate the validation and application 
of the proposed methodology, the survey for qualitative risk assessment was conducted to relevant respondents with sufficient knowledge and experience on the project being assessed. The backgrounds of respondent are mixed from public sectors, private sectors and academics to represent the different perspectives and to avoid biases. They are selected based on the relevance to actual PPP projects from different sectors (toll road, transportation, water supply and power sectors) that were assessed. To further corroborate the validity of the methodology, Indonesia's Risk Management Unit in the Ministry of Finance office has successfully applied the proposed framework for the risk assessment on the actual evaluation of a PPP project in electricity generation sector.

\section{CONCLUSIONS}

This paper proposes a comprehensive and relevant risk management framework that considering limitations of each quantitative and qualitative approach for government contingent liabilities assessment from PPP projects. Perspective of the host government is chosen as it tends to make poor decision over contingent support such as guarantees and very few governments formally measure them.

The methodology aimed to estimate comprehensively political risk factors for contingent liabilities assessment. It uses fuzzy sets based risk assessment that quantifies expert opinion on risk factors into an input to quantitative risk analysis by converting the aggregated expert opinion into risk profile specific and customized probability distribution functions (PDF) for Monte Carlo simulation.

For political risk assessment, risk factors are obtained and summarized from list of relevant factors that are usually used for underwriting political risk insurance to comprehensively provide fair and objective platform of the assessment. Furthermore, Indonesia PPP infrastructure projects and its relevant regulatory framework were used for the application of the methodology.

This paper proposes a methodology that combined quantitative and qualitative approach for contingent liabilities assessment for PPP infrastructure projects with focus on political risk. It uses fuzzy sets based risk assessment that quantifies expert opinion on likelihood and impact of risk factors into an input to quantitative risk analysis. Fuzzy sets theory is chosen because the vagueness and subjective nature of political risk that associated with its likelihood and impact assessment. A particular developing country is chosen so that the proposed methodology can be applied according to the country and infrastructure sectors specific context.

\section{ACKNOWLEDGEMENT}

The authors acknowledge the research collaboration under confidentiality agreement with Indonesia's Risk Management Unit, Ministry of Finance for development of the practical framework, possible case study applications using actual project data and the intensive discussions during the delivery of workshop series on the guarantee valuations by the first author together with Dr. Andreas Wibowo of Ministry of Public Works, Indonesia. 


\section{REFERENCES}

Almeyda, M., and Hinojosa, S. (2001). Revision of State of the Contingent Liability Management, Bibliography. Washington, D.C., World Bank.

Brixi, H. P., and Schick, A. (1999). Government at Risk: Contingent Liabilities and Fiscal Risk. Washington, DC, World Bank.

Clark, E. (1997). ”Valuing political risk.” Journal of International Money and Finance 16: 477-490.

Clemen, R. T., Winkler, R. L. (1999). "Combining probability distributions from experts in risk analysis.” Risk Analysis 19: 187-203.

Irwin, T. C. (2003). Public Money for Private Infrastructure: Deciding When to Offer Guarantees, Output-Based Subsidies, and Other Forms of Fiscal Support. Working Paper 10. Washington, DC, World Bank.

Irwin, T. C. (2007). Government Guarantees: Allocating and Valuing Risk in Privately Financed Infrastructure Projects, The World Bank.

Kosugi, T. (2006). Sovereign Risk Assessment Methodology of Japan Bank for International Cooperation. GEFRI Conference on Modelling and Managing Sovreign and Systemic Risk, 24 April, Conference Proceeding.

Levy, J. B., Yoon, Eunsang. (1995). ”Theory and Methodology: Modeling global market entry decision by fuzzy logic with an application to country risk assessment.” European Journal of Operational Research 82: 53-78.

Mahajan, A. (1990). "Pricing expropriation risk." Financial Management Winter: 77-86.

Mody, A. (2002). Contingent Liabilities in Infrastructure: Lessons from the East Asian Financial Crisis. Government at Risk: Contingent Liabilities and Fiscal Risk. Hana Polackova Brixi and Allen Schick. Washington, DC, World Bank: 373-92.

Sachs, T., Bellinger, C., Tiong, R.L.K. (2008). "Risk Exposure and Recovery Assessment under a Guarantee in a Water Project." Journal of Structured Finance(Spring): 50-64.

Saliby, E., and Pacheco, F. (2002). An empirical evaluation of sampling methods in risk analysis simulation: quasi-Monte Carlo, descriptive sampling, and Latin Hypercube sampling. Winter Proc. Simul. Conference, IEEE.

Shapiro, A. (1978). "Capital budgeting for the multinational corporation.” Financial Management Spring(7): 7-16.

Tiong, R. L. K. (1995). "Risks and Guarantees in BOT Tender.” Journal of Construction Engineering and Management 121(2): 183-188.

Wagner, D. (1999). Political Risk and Insurance Guide. United States, IRMI.

Wibowo, A. (2004). "Valuing guarantees in a BOT infrastructure project." Engineering, Construction and Architectural Management 11(6): 395-403.

Ye, S. (2001). A Study of Concession Design and Risk-Return Tradeoffs for Privately Financed Infrastructure Projects. School of Civil and Environmental Engineering. Singapore, Nanyang Technological University. PhD Thesis.

Zadeh, L. A. (2002). Probability Theory and Fuzzy Logic. Research report, Berkeley Initiative in Soft Computing (BISC) Program of UC Berkeley, USA. 
APPENDIX

\section{List of Risk Factors for Fuzzy-based Risk Assessment}

\begin{tabular}{|c|c|c|}
\hline A & Risk Factor of Expropriation risk & References: \\
\hline 1 & The project's importance (priority) to the national economy & (Wagner 1999); (Anderson 2007) \\
\hline 2 & $\begin{array}{l}\text { The project's size/impact relative to domestic industry } \\
\text { (economic value added) }\end{array}$ & (Wagner 1999); (Wagner 2006) \\
\hline 3 & The project's contribution to export earnings & (Wagner 1999) \\
\hline 4 & $\begin{array}{l}\text { The crucial aspects of the project agreement } \\
\text { to host government }\end{array}$ & (Wagner 1999); (Wagner 2006) \\
\hline 5 & The project's vulnerability to adverse economic development & (Wagner 1999) \\
\hline 6 & $\begin{array}{l}\text { Involvement of someone in power with the project } \\
\text { (raw material, etc) }\end{array}$ & (Wagner 1999) \\
\hline 7 & Impact on community, community relations of the project & (Anderson 2007) \\
\hline 8 & Environmental impact of the project & (Anderson 2007) \\
\hline 9 & The project's vulnerability to discriminatory policy (tariff, etc) & (Wagner 1999) \\
\hline 10 & Foreign ownership in the project & (Wagner 2006) \\
\hline 11 & Dependence on foreign investment and foreign aid & (Anderson 2007) \\
\hline 12 & Ideological underpinning of government & (Anderson 2007) \\
\hline 13 & The investor's overseas experience & (Wagner 1999) \\
\hline 14 & $\begin{array}{l}\text { Existing relationship between the investor's country } \\
\text { and Indonesia (Bilateral Investment Treaty, etc) }\end{array}$ & (Wagner 1999) \\
\hline 15 & $\begin{array}{l}\text { Indonesia's record of intervention or attitude } \\
\text { in foreign investment }\end{array}$ & (Wagner 1999) \\
\hline 16 & Dissident elements inclined towards expropriatory action & (Wagner 1999) \\
\hline B & Risk Factor of Currency Inconvertibility and Non Transfer & References: \\
\hline 1 & $\begin{array}{l}\text { Project structure: hard currency generation; offshore account; } \\
\text { priority access to FX }\end{array}$ & (Wagner 1999); (Wagner 2006) \\
\hline 2 & $\begin{array}{l}\text { Risk mitigation measures (stop loss, staggered payout, } \\
\text { extended waiting period, reduced insured percentage) }\end{array}$ & (Wagner 2006) \\
\hline 3 & Potential to recovery of project loss & (Wagner 1999) \\
\hline 4 & Health of balance of payments, fiscal accounts & (Anderson 2007) \\
\hline 5 & Transfer delay experience & (Wagner 2006) \\
\hline 6 & $\begin{array}{l}\text { Indonesia's exchange control system } \\
\text { (FX acquisition, approvals, insured's prior experience }\end{array}$ & (Wagner 1999); (Wagner 2006) \\
\hline 7 & Concentrated loan repayment or dividend remittances & (Anderson 2007) \\
\hline 8 & $\begin{array}{l}\text { Country's liquidity or economic outlook } \\
\text { FX reserves and import coverage) }\end{array}$ & (Wagner 2006); (Anderson 2007) \\
\hline $\mathrm{C}$ & Risk Factor of Breach of Contract & References: \\
\hline 1 & Off-taker status as sovereign, regulator or privatized company & (Wagner 1999); (Silverman 2007) \\
\hline 2 & $\begin{array}{l}\text { Settlement procedure on contractual dispute } \\
\text { (arbitration award, etc) }\end{array}$ & (Wagner 1999); (Silverman 2007) \\
\hline 3 & Decentralization of govt control of services to local authorities & (Silverman 2007) \\
\hline 4 & $\begin{array}{l}\text { Linkage between state, local and municipal authorities } \\
\text { to central govt }\end{array}$ & (Silverman 2007) \\
\hline D & Risk Factor of Change in Law Breach of Contract & References: \\
\hline 1 & Regulatory framework untested/not implemented & (Silverman 2007) \\
\hline 2 & Regulatory pronouncement & (Silverman 2007) \\
\hline 3 & Independence of regulator & (Silverman 2007) \\
\hline 4 & Regulatory quality & (Silverman 2007) \\
\hline 5 & Rule of law & (Anderson 2007); (Donnelly 2007) \\
\hline
\end{tabular}




\section{List of Trigger Events for Subjective Probability Assessment}

\begin{tabular}{|c|c|c|}
\hline A & Trigger event of Expropriation risk & References: \\
\hline 1 & Change of government and then violate local/international law & (Wagner 1999) \\
\hline 2 & Political or economic situation & (Wagner 1999) \\
\hline 3 & Discriminatory action politically & (Wagner 1999) \\
\hline 4 & Cancellation of license politically & (Wagner 1999) \\
\hline 5 & Tax disputes & (Wagner 1999) \\
\hline 5 & Blocked bank account politically & (Wagner 1999) \\
\hline 6 & Legislative action & (Wagner 1999) \\
\hline 7 & Seize the assets \& not adequately compensate (direct) & (Wagner 1999) \\
\hline 8 & Forced sale of assets (creeping) & (Wagner 1999) \\
\hline 9 & Interfere ownership rights (creeping) & (Wagner 1999) \\
\hline B & Trigger event of Currency Inconvertibility and Non Transfer & \\
\hline 1 & Currency devaluation & (Wagner 1999) \\
\hline 2 & Conversion process $>180$ days (CI-Passive Blockage) & (Wagner 1999) \\
\hline 3 & Expropriation of funds & (Wagner 1999) \\
\hline 4 & CI-Active Blockage (by a law) & (Wagner 1999) \\
\hline 5 & Currency non-transfer & (Wagner 1999) \\
\hline $\mathrm{C}$ & Trigger event of Change in Law & \\
\hline 1 & Enactment of a new law or enactment of a law in a new law territory. & $\begin{array}{l}\text { (Prasetya Mulya } \\
\text { Business School 2007) }\end{array}$ \\
\hline 2 & Annulment, amendment or re-enactment of a law. & $\begin{array}{l}\text { (Prasetya Mulya } \\
\text { Business School 2007) }\end{array}$ \\
\hline 3 & $\begin{array}{l}\text { Enactment of a law that has not valid effectively until certain Effective } \\
\text { Date. }\end{array}$ & $\begin{array}{l}\text { (Prasetya Mulya } \\
\text { Business School 2007) }\end{array}$ \\
\hline 4 & $\begin{array}{l}\text { Change of interpretation or enactment of a law using interpretation } \\
\text { or enactment by Constitutional Court and/or Supreme Court after } \\
\text { Effective Date. }\end{array}$ & $\begin{array}{l}\text { (Prasetya Mulya } \\
\text { Business School 2007) }\end{array}$ \\
\hline 5 & Any change on any government tax rate. & $\begin{array}{l}\text { (Prasetya Mulya } \\
\text { Business School 2007) }\end{array}$ \\
\hline $\mathbf{D}$ & Trigger event of Breach of Contract & \\
\hline 1 & A change of tariff rate in purchase agreement (PPA, etc) & (Wagner 1999) \\
\hline 2 & $\begin{array}{l}\text { Legal dispute in investment or concession agreement (Investor vs host } \\
\text { govt) }\end{array}$ & (Wagner 1999) \\
\hline 3 & $\begin{array}{l}\text { The government fails to fulfil its actual obligation that resulting } \\
\text { negative impacts the rights and the authorities of the project } \\
\text { company's business }\end{array}$ & $\begin{array}{l}\text { (Prasetya Mulya } \\
\text { Business School 2007) }\end{array}$ \\
\hline 4 & $\begin{array}{l}\text { The government fails to fulfil its main obligation based in the } \\
\text { agreement esp. the obligation on land provision according to } \\
\text { Concession Agreement }\end{array}$ & $\begin{array}{l}\text { (Prasetya Mulya } \\
\text { Business School 2007) }\end{array}$ \\
\hline
\end{tabular}


APPENDIX

\section{The Diagram of Proposed Risk Assessment Framework}

The overall analytical framework of the fuzzy logic-based risk assessment used for government guarantee valuation for political risk in PPP infrastructure projects is described bellow.

It integrates qualitative and quantitative approach to be conducted by team of analyst for decision making process on government guarantee policy by Minister of Finance. The team is also responsible for estimating the adequate amount and budgeting of capital reserve to serve the guarantee claim payment and is conducted for individual project requesting for political risk as the guarantee coverage.

Qualitative Risk Assessment

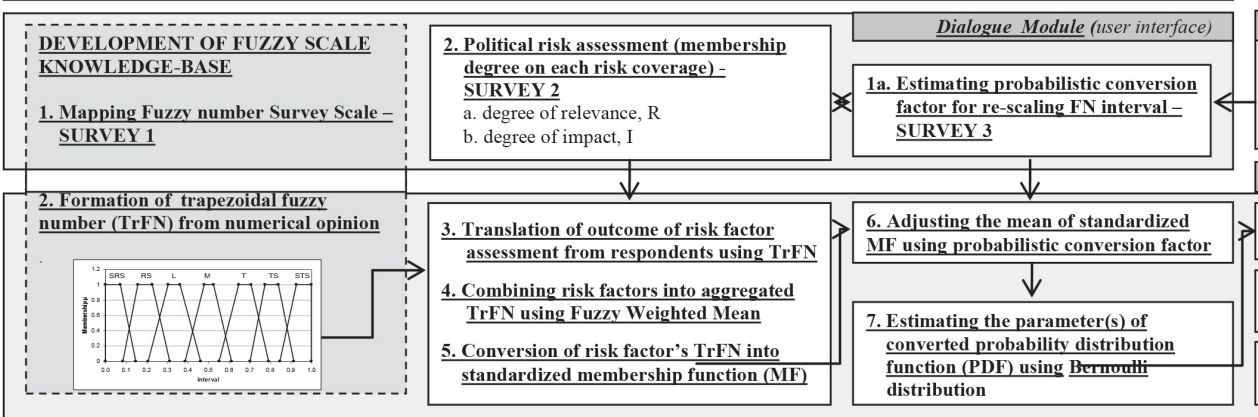

Quantitative Risk Modelling and Simulation Application Module (implementation context) DEVELOPMENT OF RISK FACTOR KNOWLEDGE BASE According to the guarantee risk coverage Engine Module modeling and computation

1b. Selection of applicable risk event and its type of dist

8. Modelling the guarantee risk exposure and non political risk variable

9. Guarantee Stochastic Valuation and Impact Evaluation on Project Feasibility 